\title{
PENERAPAN KONTEN E-LEARNING BERBASIS SCORM UNTUK MENINGKATKAN EFEKTIVITAS PEMBELAJARAN
}

\author{
Siti Husnul Bariah ${ }^{1}$, Soni Muhamad Sidik ${ }^{2}$ \\ Pendidikan Teknologi Informasi, Institut Pendidikan Indonesia \\ Jl. Pahlawan No.32, Sukagalih, Tarogong Kidul, Garut. \\ ${ }^{1}$ sitihusnulbariyah@gmail.com \\ ${ }^{2}$ sonimuhamadsidik71@gmail.com
}

\begin{abstract}
E-learning is one form of learning model that is facilitated and supported by the use of information and communication technology. In an education such as high school it is very necessary to help teachers improve the effectiveness of observer learning / temporary research related to the process of learning students in receiving material is still focused on existing textbooks, the application of technology is still less used in learning so it feels less effective in delivering material so students feel bored. Therefore there needs to be a renewal in learning to improve learning effectiveness. This study aims to obtain information about the following matters. Transformation of presentation of standardized scorm material (Sharable Content Object Refrence Model), where teachers can find out student activities in teaching and learning activities specifically in reading teaching materials provided by teachers and the extent to which the effectiveness of learning can be improved by learning using standardized scorm e-learning. In this study researchers used quantitative methods and the type of research used was quasi-experimental. This study uses two classes namely class $X 1$ as the experimental class and class $X 2$ as the control class. The results obtained from this study, obtained in the form of preliminary data, namely the pretest for the experimental class with an average value of 59.5 while the control class received an average value of 49.1. After applying e-learning based on scorm and after getting treatment for the experimental class, the posttest value was obtained with an average of 81.8 with an increase of $38 \%$ and a control class of 62.1 with a level of $27 \%$. And the response of students' responses was so good towards the application of scorm-based e-learning with data that was proven by obtaining data that 25 students or $94.29 \%$ of Class X 1 students gave very good responses and 2 students or $5.71 \%$ gave good responses. Conclusion that the placement of scorm-based e-learning content can increase the effectiveness of learning.
\end{abstract}

Keywords: Effectiveness of Learning, e-learnign based on scom

\begin{abstract}
Abstrak - E-learning merupakan salah satu bentuk model pembelajaran yang difasilitasi dan didukung pemanfaatan teknologi informasi dan komunikasi. Pada sebuah pendidikan seperti Sekolah Menengah Atas sangat dibutuhkan untuk membantu guru dalam meningkatkan efektifitas pembelajaran Beradasrkan pengamat/penelitian sementara yang berkaitan dengan proses pemebelajaran siswa dalam menerima materi masih terfokus pada buku - buku paket yang ada, penerapan teknolgi masih kurang digunakan dalam pembelajaran sehingga terasa kurang efektif dalam penyampaian materi sehingga siswa merasa jenuh. Oleh sebab itu perlu adanya pembaharuan dalam pembelajaran untuk meningkatkan efektifitas pembelajaran. Penelitian ini bertujuan untuk memperoleh informasi mengenai hal-hal berikut. Transformasi penyajian materi berstandarisasi scorm (Sharable Content Object Refrence Model), dimana guru dapat mengetahui aktivitas siswa dalam kegiatan belajar mengajar khususnya dalam membaca bahan ajar yang disediakan oleh guru dan sejauh mana efektifitas pemeblajaran dapat ditingkatkan dengan pemebelajaran menggunakan elearning berstandarisasi scorm. Pada penelitian ini peneliti menggunakan metode kuantitatif dan jenis penelitian yang digunakan adalah kuasi eksperimen. Penelitian ini menggunakan dua kelas yaitu kelas X 1 Sebagai kelas eksperimen dan kelas X 2 sebagai kkelas Kontrol. Hasil yang didapat dari penelitian ini, didapat berupa data awal yaitu pretest untuk kelas eksperimen dengan nilai rata - rata adalah 59,5 sedangan kelas kontrol mendapatkan nilai rata - rata 49,1. Setelah diterapkan e-learning berbasi scorm dan setelah mendapat perlakuan untuk kelas eksperimen didapat nilai postes dengan rata - rata 81,8 dengan taraf peningkatan 38\% dan kelas kontrol sebesar 62,1 dengan taraf 27\%. Dan respon tanggapan siswa begitu baik
\end{abstract}


terhadap penerapan e-learning berbasis scorm ini dengan data yang dibuktikakn dengan diperoleh data bahwa 25 siswa atau 94,29\% siswa Kelas X 1 memberi tanggapan sangat baik dan 2 siswa atau 5,71\% memberi tanggapan baik. Kesimpulan bahwa penerpan konten e-learning berbasis scorm dapat meningkatkna efektifitas pembelajaran.

Kata Kunci : Efektivitas Pembelajaran, e-learnign berbasis scom

\section{PENDAHULUAN}

Pengetahuan dan pembelajaran merupakan dua hal yang tidak dapat terpisahkan satu sama lain. Pengetahuan adalah informasi yang didapat oleh seseorang secara sadar meliputi emosi, keterampilan, informasi, dan pikiran -

pikiran sehingga seseorang dapat mengungkapkan apa yang ada di-pikirannya berdasarkan pengalamannya. Pembelajaran adalah suatu proses kegiatan yang ditata dan diatur sedemikian rupa supaya memperoleh informasi baru.

Dalam kegiatan belajar mengajar pendidik perlu menyiapkan sebuah perangkat pembelajaran untuk mendukung kegiatan belajar tersebut. Dengan adanya sebuah perangkat pembelajaran memudah-kan peserta didik untuk mendapatkan berbagai referensi belajarnya. Di era teknologi informasi seperti ini ditunjang dengan semakin meningkatnya akses internet peserta didik dapat dengan mudah mencari referensi sesuai yang meraka butuhkan melalui jaringan internet.

Penerapan suatu model pembelajaran memiliki satu komponen yang perlu diperhatikan agar suatu model pembelajaran dapat berkesinambungan dan memberikan pengaruh dalam pelaksanaannya.Komponen tersebut yaitu desain aplikasi, dan manajemen atau maintenance. Berkaitan dengan pembelajaran, pemanfaatan teknologi informasi dalam hal ini e-learning diperlukan tidak hanya pendidik yang terampil memanfaatkan teknologi serta teknologi untuk pembuatan bahan ajar, akan tetapi diperlukan suatu rancangan agar dapat melaksanakan pembelajaran dengan efektif. Dalam sebuah rancangan pembelajaran (desain instruksional) terdapat suatu proses untuk memandu pelaku (aktor) untuk mendesain, mengembangkan, menerapkan konten e-learning dengan memanfaatkan infrastruktur dan aplikasi elearning yang tersedia. Pada tahap selanjutnya dalam implementasi e-learning terdapat tahap evaluasi yang dimanfaatkan untuk merevisi atau penyesuaian terhadap tahap-tahap sebelumnya. Desain instruksional merupakan proses dinamis yang dapat berubah-ubah sesuai dengan informasi dan evaluasi yang diterima bertujuan untuk meningkatkan hasil pembelajaran peserta didik sehingga tujuan pembelajaran dapat tercapai.

E-learning merupakan salah satu bentuk model pembelajaran yang difasilitasi dan didukung pemanfaatan teknologi informasi dan komunikasi. E-learning mempunyai ciri-ciri, antara lain (Clark \& Mayer 2008:10): 1) memiliki konten yang relevan dengan tujuan pembelajaran, 2) menggunakan metode instruksional, misalnya penyajian contoh dan latihan untuk meningkatkan pembelajaran, 3)menggunakan elemen-elemen media seperti kata-kata dan gambar - gambar untuk menyampaikan materi pembelajaran, 4) memung-kinkan pembelajaran langsung berpusat pada pengajar (synchronous e-learning) atau di desain untuk pembelajaran mandiri(asynchronous e-learning), 5)membangun pemahaman dan keterampilan yang terkait dengan tujuan pembelajaran baik secara perseorangan atau meningkatkan kinerja pembelajaran kelompok.

Moodle adalah program aplikasi yang dapat mengubah sebuah media pembelajaran kedalam bentuk web. Produk e-learning berbasis Moodle memungkinkan siswa untuk masuk kedalam "ruang kelas digital" untuk mengakses materi-materi pembelajaran. Kelebihan dari Moodle antara lain dapat membuat materi pembelajaran, kuis, forum diskusi secara online dalam suatu kemasan $e$ learning. Siswa diharapkan dapat lebih memahami materi dengan media pembelajaran ini, karena dapat mengakses lebih banyak informasi yang ada pada e-learning Moodle. Selain itu, inovasi media pembelajaran yang ditawarkan diharapkan dapat meningkatkan mutu pembelajarannya. Pada penelitian ini peneliti menggunakan fitur dari activity moodle yaitu adalah scorm. SCORM (Shareble Content Object Reference Model) merupakan standarisasi pendistribusian konten $e$ Learning yang dikeluarkan oleh ADL (Advanced Distributed Learning). Dengan ini, guru dapat membuat paket yang berisi 
halaman web, grafis, slide presentasi Flash, video, suara dan konten apapun yang dapat dibuka di web browser (Rianto,S.2013). Dengan menggunakan format SCORM maka materi pembelajaran dapat digunakan dimana saja pada apalikasi e-learning lain yang mendukung SCORM. Saat ini telah banyak aplikasi $e$ learning yang mendukung format SCORM ini. Dengan demikian maka antar lembaga pendidikan, sekolah dapat saling bertukar materi e-learning untuk saling mendukung materi pembelajaran elektronik ini. Guru cukup membuat sebuah materi e-learning dan menyimpannya dalam file dengan format SCORM dan memberikan materi pembelajaran tersebut dimanapun guru itu bertugas.

Salah satu sekolah menengah atas yang secara konsisten ingin meningkatkan mutu dan kualitas pendidikan dengan memanfaatkan teknologi informasi dan komunikasi adalah SMA Baitul Hikmah. SMA Baitul Hikmah merupakan sekolah menengah atas yang ingin sekali memanfaatkan e-learning dalam setiap pembelajarannya. Pemanfaatan e-learning pada sebuah pendidikan seperti Sekolah Menengah Atas sangat dibutuhkan untuk membantu guru dalam meningkatkan efektifitas pembelajaran.Seperti telah diketahui pembelajaran yang digunakan terkesan monoton tidak berinovasi sehingga pemebelajaran yang disampaikan terkesan tidak efektif.

Setelah dilakukan observasi awal di SMA Baitul Hikmah, diperoleh informasi bahwa pembelajaran berbasis online masih belum begitu dikembangkan bahkan tidak di terapkan sama sekali, siswa hanya terfokus di dalam kelas dan buku untuk belajar tidak adanya pembaharuan untuk meningkatkan dalam efektifitas pembelanya, dari observasi itu juga di dapat informasi yang mana guru masih belum terbiasa menggunakan pembelajaran e-learning, Pendistribusian bahan ajar berupa media powerpoint yang sudah dilakukan oleh guru matapelajaran Biologi di SMA Baitul Hikmah diantaranya melalui pertemuan tatap muka langsung ketika pembelajaran berlangsung, setelah selesai biasanya transfer melalui media penyimpanan kepada salah satu siswa kemudian siswa tersebut membagikannya ke teman - teman melalui jejaring social atau grup kelas masing-masing atau guru membuat sebuah bahan ajar cetak kemudian mewajibkan seluruh siswa untuk mengkopi diktat tersebut. Hal lain yang digunakan dalam pendistribusian bahan ajar yaitu dengan pemanfaatan sistem e-learning.

Akan tetapi dengan pembelajaran menggunakan e-learning perlu adanya pengawasan dari guru untuk pelaksanaan pemebelajaran, guru dalam hal pemebelajaran ini sulit untuk mengawasi apakah siswa belajar atau tidak, bahkan siswa yang belajar guru tetap tidak bisa melihat apakah dalam belajarnya siswa itu membaca materi sampai selesai atau tidak. Sehingga pembelajaran $e$ learning ini sangat perlu adanya pengawasan dari guru, agar efektifitas dari pembelajaran yang sesungguhnya dapat tercapai. Penggunaan scorm ini guru dapat melihat atau memantau sejauhmana siswa itu belajar dam menyelesaikan materi yang siswa pelajari.

Penelitian ini dimaksudkan untuk mengetahui dari konten e-learning berbasis standarisasi SCORM di Sma Baitul Hikmah dalam meningkatkan efektivitas peembelajaran, yang lainnya, memudahkan kepada mahasiswa dalam mengakses materi tersebut, membuat sebuah kebiasaan baru bahwa mahasiswa membuka e-learning tidak hanya mengaksesnya semata-mata hanya untuk mendownload materi saja atau hanya dapat notif bahwa mahasiswa tersebut sudah mengaksesnya.

\section{KAJIAN PUSTAKA}

\section{a. Model pembelajaran konstruktivisme}

Model pembelajaran konstruktivisme adalah salah satu pandangan tentang proses pembelajaran yang menyatakan bahwa dalam proses belajar (perolehan pengetahuan) diawali dengan terjadinya konflik kognitif. Konflik kognitif ini hanya dapat diatasi melalui pengetahuan akan dibangun sendiri oleh anak melalui penga-lamannya dari hasil interaksi dengan lingkungannya. Menurut Werrington (dalam Suherman, 2003:75), menyatakan bahwa dalam kelas konstruktivis seorang guru tidak mengajarkan kepada anak bagaimana menyelesaikan persoalan, namun mempresentasikan masalah dan mendorong siswa untuk menemukan cara mereka sendiri dalam menyelesaikan permasalahan. Ketika siswa memberikan jawaban, guru mencoba untuk tidak mengatakan bahwa jawabannya 
benar atau tidak benar. Namun guru mendorong siswa untuk setuju atau tidak setuju kepada ide seseorang dan saling tukar menukar ide sampai persetujuan dicapai tentang apa yang dapat masuk akal siswa. Di dalam kelas konstruktivis, para siswa diberdayakan oleh pengetahuannya yang berada dalam diri mereka. Mereka berbagi strategi dan penyelesaian, debat antara satu dengan lainnya, berfikir secara kritis tentang cara terbaik untuk menyelesaikan setiap masalah. Beberapa prinsip pembelajaran dengan pendekatan konstruktivis diantaranya bahwa observasi dan mendengar aktivitas dan pembicaraan matematika siswa adalah sumber yang kuat dan petunjuk untuk mengajar, untuk kurikulum, untuk cara-cara dimana pertumbuhan pengetahuan siswa dapat dievaluasi.

\section{b. E-LEARNING}

Kata e-learning terdiri dari dua bagian, yaitu " $e^{e e}$ yang merupakan singkatan dari ,electronic" dan learning yang berarti "pembelajaran". Jadi, e-learning berarti pembelajaran dengan menggu-nakan jasa bantuan perangkat elektronika, khususnya perangkat komputer. Karena itu, maka $e$ learning sering disebut pula dengan ,online course $^{\text {ee }}$ (Kusmana 2011). Lanzilotti (2006) juga menambahkan bahwa e-learning menjadi sangat penting di berbagai bidang untuk mempermudah akses materi pembelajaran menjadi lebih efektif dan efisien untuk mewujudkan pendidikan seumur hidup. mengemukakan bahwa e-learning merupakan bagian dari Integrated Learning Design Framework (ILDF). Model ILDF adalah model desain pembelajaran yang khusus dikembangkan untuk proses belajar masa depan, yaitu online e-learning atau web-based learning yang mengoptimalkan pemanfaatan teknologi telekomunikasi. Model e-learning dikatakan termasuk 11 dalam model ILDF karena memiliki ciri khas yang sesuai dengan model ini. Ciri khas model ILDF menurut Prawiradilaga (2004) adalah berorientasi pada proses belajar menggunakan virtual classroom, mengangkat masalah yang perlu dihilangkan batasan waktu dan geografisnya, dan jenis pembelajaran yang disusun berupa pembelajaran mandiri dengan konten yang biasa ada pada pembelajaran di kelas dengan sistem tatap muka. Berdasarkan kekhasan model yang dikemukakan Prawiradilaga, peneliti memilih pembelajaran semi virtual classroom. Jadi, pembelajaran tidak sepenuhnya terlaksana di kelas maya, tapi juga digabungkan dengan pembelajaran di kelas nyata. Pembelajaran materi Sistem Gerak yang masih menggunakan sistem kelas nyata dengan komunikasi yang terbatas hanya terjadi di kelas. Untuk itu, melalui pembelajaran di kelas maya, kekurangan pembelajaran di kelas nyata diharapkan dapat teratasi.

\section{c. SCORM}

Sharable Content Object Refrence Model (SCORM) adalah standar yang dikembangkan oleh Advanced Distributed learning (ADL) yang kemudian di support oleh United States Secretary of Defences (USSD) sebagai sebuah standar e-learning. Sejak dikembangkan mulai tahun 2000, saat

ini hampir semua LMS yang beredar sudah menerima standar SCORM sebagai standar paket konten untuk modul pembelajaran. Menurut Rice (dalam Susanty dan Oriniati, 2013:45) SCORM (Shareable Content Object Reference Model) adalah standar pendistribusian paket e-Learning yang dapat digunakan untuk menampung berbagai spesifikasi dan standar untuk konten e-Learning berbasis web dengan mengacu pada interoperability, accesibility, dan reusability. Menurut Susanty dan Oriniati (2013:45) Tujuan dari SCORM adalah sebuah upaya untuk mulai menyeragamkan pengem-bangan sistem eLearning berbasiskan teknologi web yang disebut Learning Management Systems (LMS). SCORM menggunakan pendekatan object oriented dan memandang bahwa setiap learning object atau content object sebagai sekumpulan objek yang dapat disatukan

\section{d. Efektifitas Pemebelajaran}

Penerapan teknologi dalam pembelajaran ditengarai dapat mening-katkan hasil pembelajaran. Pembelajaran berbasis teknologi informasi dan komunikasi akan berjalan efektif jika peran pengajar dalam pembelajaran adalah sebagai fasilitator pembelajaran atau memberikan kemudahan pembelajar untuk belajar bukan hanya sebagai pemberi informasi. Proses pembelajaran dengan memanfaatkan teknologi informasi dan komunikasi merupakan bimbingan dari 
pengajar untuk memfasilitasi pembelajaran pembelajar yang efektif (Munir, 2009:3).

$$
\text { Menurut Popham (2003:7), }
$$
efektivitas proses pembelajaran seharusnya ditinjau dari hubungan guru tertentu yang mengajar kelompok siswa tertentu, di dalam situasi tertentu dalam usahanya mencapai tujuan-tujuan instruksional tertentu. Efektivitas proses pembelajaran berarti tingkat keberhasilan guru dalam mengajar kelompok siswa tertentu dengan menggunakan metode tertentu untuk mencapai tujuan instruksional tertentu.

Dunne (1996:12) berpendapat bahwa efektivitas pembela-jaran memiliki dua karakteristik. Karakteristik pertama ialah "memu-dahkan murid belajar" sesuatu yang bermanfaat, seperti fakta, keterampilan, nilai, konsep atau sesuatu hasil belajar yang diinginkan. Kedua, bahwa keterampilan diakui oleh mereka yang ber-kompeten menilai, seperti guru, pengawas, tutor atau murid sendiri. Sedangkan menurut Miarso (2004) mengatakan bahwa efektivitas pembelajaran merupakan salah satu standart mutu pendidikan dan sering kali diukur dengan tercapainya tujuan, atau dapat juga diartikan sebagai ketepatan elola suatu situasi, "doing the right things".

\section{METODOLOGI PENELITIAN}

a. Definisi Operasional atau penjelasan Variabel

1. E-learning adalah pembelajaran yang menggunakan rangkaian elektronik (LAN,WAN atau internet),untuk menyampaikan pembelajaran,interaksi,atau bimbingan.

2. Scorm (Shareable Content Object Reference Model) adalah standar pendistribusian paket e-learning yang dapat digunakan untuk menampung berbagai spesifikasi dan standar untuk konten e-learning berbasis web dengan mengacu pada interoperability, accesibility, dan reusability (Rice 2006).

3. Efktifitas Pembelajaran usaha pembelajaran yang berkriteria daya tarik atau daya guna, artinya dengan pemanfaatan seperangkat karakteristik tersembunyi dosen menolong siswa mencapai tujuan pembelajaran. Dengan kata lain efektifitas adalah salah satu indicator dari proses pembelajaran yang baik. Indikator lainnya adalah efisiensi dan produktifitas.

\section{b. Metode Penelitian}

Metode penelitian yang digunakan penulis dalam penelitian ini adalah metode kuantitatif dan jenis penelitian yang digunakan adalah kuasi eksperimen. Dalam menentukan metode penelitian, peneliti menerima keadaan subjek seadanya dan tidak mengelompokan ke dalam kelompok - kelompok baru dikarena-kan keterbatasan izin dari pihak sekolah. Hal ini sesuai dengan yang diungkapkan Ruseffendi (Asmar:2015) bahwa pada kuasi eksperimen ini subjek tidak dikelompokan secara acak, tetapi peneliti menerima keadaan subjek seadanya. Berdasarkan kondisi tersebut, maka kuasi eksperimen adalah metode yang cocok digunakan dalam penelitian ini.

Dalam penelitian ini terdapat dua kelompok yaitu kelompok eksperimen dimana pembelajarannya menggunakan e-learing berbasis scorm dan kelompok kontrol yang pembelajarannya menggunakan model pembelajaran konvensional.

\section{c. Populasi dan Sampel Penelitian}

1. Populasi Penelitian

Populasi didefinisikan sebagai keseluruhan subjek penelitian, kumpulan dari individu dengan kualitas serta ciri - ciri yang telah ditetapkan, dan sekumpulan obyek yang lengkap dan jelas (Rahadi, 2009:49). Populasi dalam penelitian ini adalah seluruh siswa kelas X SMA Baitul Hikmah tahun ajaran 2016 / 2017.

2. Sampel Penelitian

Sampel adalah sebagian dari populasi, cara pengambilan sampel disebut dengan sampling (Rahadi, 2009:49). Pengambilan sampel dalam peneleitian ini dilakukan acak kelas yang akan mewakili populasi. Sampel dalam penelitian ini adalah siswa kelas X-1 sebagai kelas eksperimen dan kelas X-2 sebagai kelas kontrol, karena kelas tersebut merupakan kelas yang telah memenuhi persyaratan untuk dijadikan kelas penelitian diantaranya pembelajaran masing konvensional belum menggunakan pemebelajaran e-learning.

\section{d. Waktu dan tempat Penelitian}

Berdasarkan pertimbangan peneliti, maka waktu penelitian ini dilaksanakan pada tanggal 8 Mei s.d. 22 Mei 2017. Jadwal pembelajaran penelitian disesuaikan dengan jadwal pembelajaran Biologi pada kelas yang bersangkutan. Tempat penelitian yaitu di SMA Baitul Hikmah.

\section{e. Instrumen Penelitian}


Instrumen penelitian adalah alat atau fasilitas yang digunakan oleh peneliti dalam mengumpulkan data agar pekerjaannya lebih mudah dan hasilnya lebih baik, dalam arti lebih cermat, lengkap, dan sistematis sehingga lebih mudah diolah (Arikunto, 2006:160).

\section{Hasil Penelitian Dan Pembahasan}

\section{a. Hasil Penelitian}

Penelitian dilakukan terhadap siswa kelas X SMA Baitul Hikmah Tarogong Kaler, dengan sampel kelas X 1 berjumlah 25 untuk kelas eksperimen dan kelas X 2 berjumlah 25 untuk kelas kontrol. Data yang diperoleh dari penelitian ini berupa data pretest dan data posttest. Data datat tersebut akan digunakan untuk mendeskripsikan data secara kuantitatif, sehingga akan diperoleh kesimpulan hasil penelitian untuk pengujian hipotesis. Data hasil belajar siswa yang diambil saat pretest.

\section{b. Pembahasan Hasil Penelitian}

\section{Pengemasan konten E-Learning Berbasis Scorm}

Setelah dilakukan penelitian, maka diperoleh data hasil penelitian, penerapan konten e-learning berbasis scrom pada penelitian ini dalam proses pengemasan konten e-learning ini membutuhkan beberapa aplikasi. Produk e-learning berbasis scorm pada materi tumbuhan berbiji yang dibuat terdiri dari bagian pendahuluan dan bagian isi. Untuk dapat mengakses fitur-fitur dalam e-learning, seseorang harus terdaftar sebagai user. Pada $e$ learning yang digunakan terdapat 1 macam user. User "admin" dijalankan oleh penyusun. Hak akses yang dimiliki admin adalah menambah dan mengurangi isi course serta melakukan pengelolaan nilai. User" teacher" dapat melakukan pengelolaan nilai. Siswa juga dibuatkan akun sebagai user "siswa" dengan metode upload multi user dan dapat mengakses seluruh isi course.

E-learning yang digunakan merupakan hasil pembuatan dari Moodle 2.4. Pada elearning terdapat 2 bagian utama, yaitu resources dan activities. Resources berisi sumber belajar berupa materi dalam berbagai format pada pembuatan materi peneliti menggunakan aplikasi Ms.Office dan Ms.Power Point dengan ekstensi .doc dan .ppt, dan di gabung dengan aplikasi Ispring agar dapat dibuka dalam bentuk format scorm dan bisa dilihat pada gambar berikut:

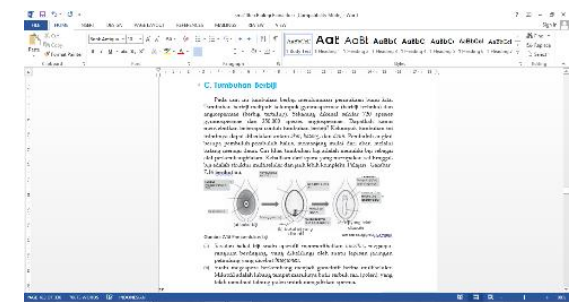

Gambar 4.1 Materi Berformat .doc

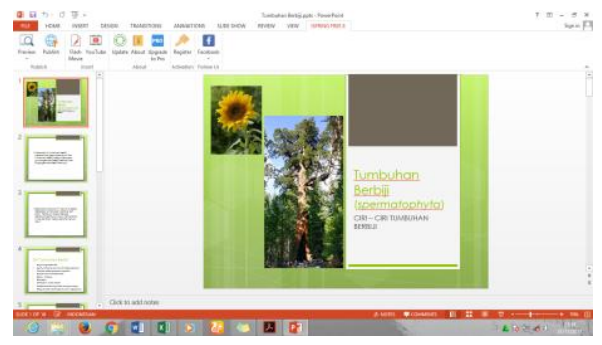

Gambar 4.2 Materi Dirubah Kedalam Format .ppt

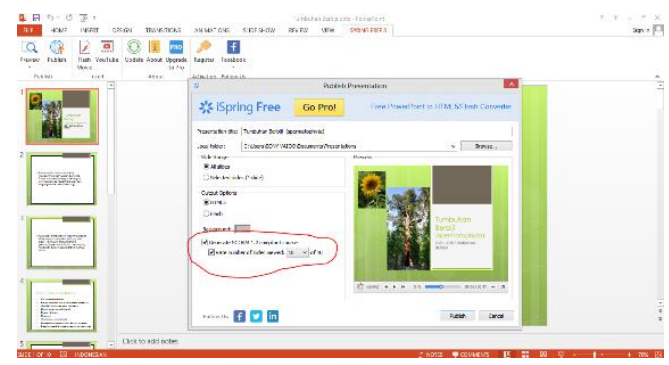

Gambar 4.3 Materi Diubah Kedalam Format Scorm

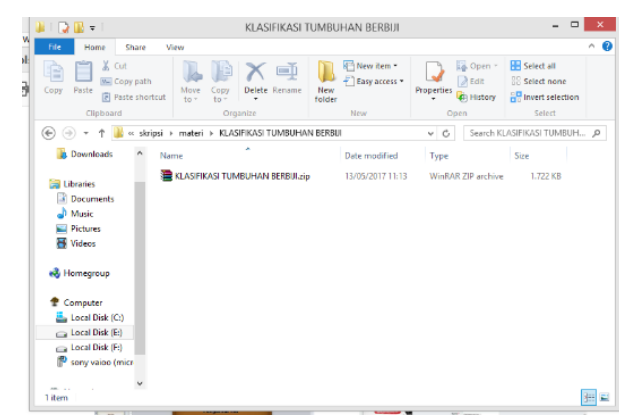

Gambar 4.4 Bahan Ajar Dikemas Berbentuk zip

sedangkan activities berisi fasilitas kegiatan yang dapat dilakukan siswa. Bahasa pada e-learning terdiri dari Bahasa Indonesia dan Bahasa Inggris. Siswa dapat memilih bahasa pengantar menu e-learning yang mereka inginkan. 


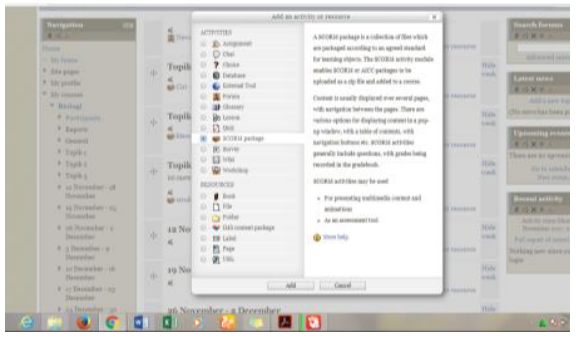

Gambar 4.5 Aktifitas Dalam LMS Moodle

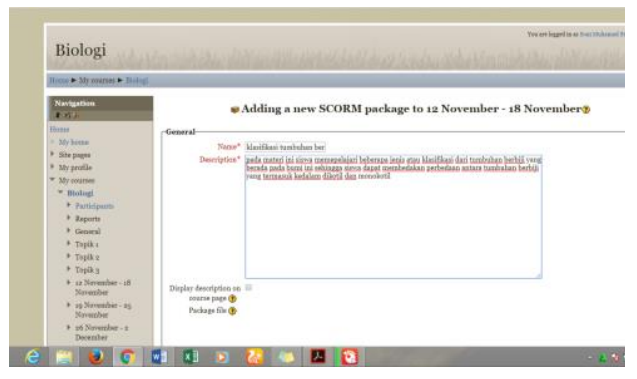

Gambar 4.6 Aktifitas Model Scorm

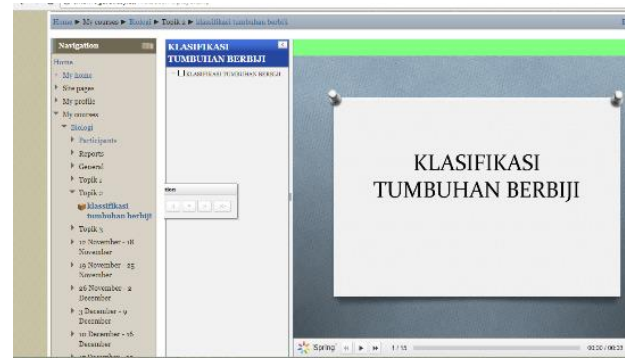

Gambar 4.7 aktifitas siswa dalam belajar dengan menggunkan Scorm

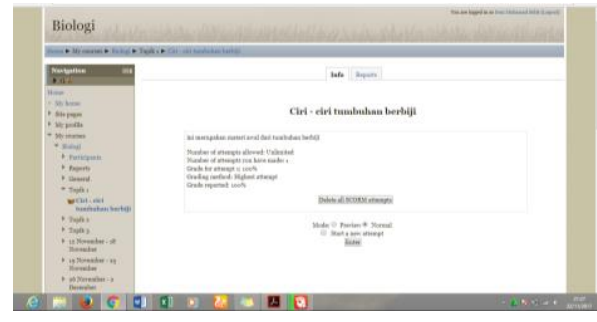

Gambar 4.8 Konten dengan standarisasi Scorm yang telah diakses oleh siswa

Pada pelaksanaan penelitian guru hanya menjadi seorang fasilitator untuk siswa yang belajar menggunakan elearning berbasis scorm ini siswa belajar hanya bersumber dari $e$ learning tersebut yang sudah disediakan oleh guru, scorm disini adlah sebuah activities yang disediakan oleh moodlle moodlle untuk fasilitas belajar siswa yang menggunakan e-learning. Pada dasarnya siswa dalam menggunakan $e$ - learning ini hanya bias membaca materi dan meng download materi yang disediakan oleh guru, sehingga pengawasan yang dilakukan oleh guru tidak terlalu signifikakn bahkan guru akan kesulitan dalam mengecek sejauh mana mereka belajar. Pada gamabar dibawah ini menunjukan sebuah fasilitas yang dapat digunakan oleh guru untuk mengecek apakah siswa itu belajar atau tidak.

\section{Efektifitas Pembelajaran dengan Penerapan E-Learning Berbasis Scrorm}

Penelitian ini dilakukan selama 3 kali pertemuan untuk masing-masing kelas. Pembelajaran pada kelas eksperimen dilakukan dengan penerapan konten e-learning berbasis scorm dan kelas kontrol menggunakan pembelajaran konvensional. Pada penerapan konten e-learning berbasis scorm ini siswa pertama kali diberi arahan oleh peneliti cara mengakses dari e-learning tersebut dan diberi akun dari masing - masing siswa,dan didapat hasil dari kunjungan siswa selama penelitian dari pertemuan pertama sampai dengan pertemuan ketiga atau terakhir yang terdapat pada tabel 4.6, 4.7, 4.8. pada pertemuan pertama yaitu pada materi pengenalan tumbuhan berbiji didapat siswa yang berkunjung sebanyak 23 orang dengan jumlah rata - rata nilai kunjungan sebesar 82,5, pada pertemuan kedua dengan materi tentang kalsifikasi tumbuhan berbiji peneliti masih memperlakukan sama terhadap kelas eksperimen dimana pembelajaran masih menerapkan e-learning berbasis scorm namun pada pertemuan kedua terdapat perbedaan yang cukup signifikan dari hasil data kunjungan siswa terdapat hanya 18 orang yang berkunjung dengan dilandasi beberap faktor antara lain siswa tidak masuk sekolah dan adanya kegiatan sekolah yang menghambat dari belajar siswa, hasil nilai rata - rata kunjungan pada materi kedua ini sebesar 53,48 terjadi penurunan sebanyak 29,02 atau 0,29\%, namun pada pertemuan ketiga dengan materi struktur tumbuhan berbiji terdapat peningkatan siswa yang mengakses dari e-learning tersebut sebanyak 24 orang dengan perolehan nilai ratarata yang didapt sebesar 88,5 artinya terdapat peningkatan yanng cukup signifikan dari pertemuan ketiga ini dengan selisih dari pertemuan kedua yaitu 35,02 atau $0,35 \%$.

Setelah diterapkan pembelajaran dengan menggunakan media e-learning berbasis scorm pada kelas eksperimen dan pembelajaran menggunakan metode konvensional pada kelas 
kontrol, dilaksanakan posttest untuk kelas eksperimen dan kelas kontrol. Untuk menegtahui apakah penerapan konten $e 3$. learning berbasis scorm dapat meningkatkan efektifitas pembelajran atau tidak. Dalam menentukan efektifitas pembelajaran, menurut Sinambela (2006:78), pembelajaran dikatakan efektif apabila mencapai sasaran yang diinginkan, baik dari segi tujuan pembelajaran maupun prestasi siswa yang maksimal.

Berdasarkan hasil yang didapat pada kelas eksperimen untuk nilai rata - rata postest lebih besar yaitu 81,8 dengan taraf peningkatan sebanyak $38 \%$ sedangkan nilai rata-rata kelas kontrol yaitu 62,1 denggan taraf peningkatan hanya $27 \%$. artinya siswa merespon baik dalam hal pembelajaran dengan penerapan konten $e$ learning berbasis scorm. Dan dapat dilihat juga untuk memperkuat bukti bahwa penerapan konten e-learning berbasis Sorm lebih efektif digunakan dengan kelas kontrol yang menggunakan metode pembelajaran konvensional. Meskipun dalam pelaksanaan terdapat penurunan pada pertemuan kedua. Dan hal ini juga dilihat dari hasil penelitian yang dilakukan oleh (Desinta Dwi Nuriyanti, 2013) sebelumnya dengan menggunakan e-learning hasil belajar siswa dapat meningkat dan melampaui KKM yang suduah ditentukan yaitu sebesar 75 .

Selain hasil belajar yang menjadi indikator efektif atau tidaknya suatu pembelajran adalah pengelolaan waktu pembelajaran yang digunakan, pada penelitian ini mempunyai renspon yang baik seperti hasil dari respon siswa pada angket yang diberikan banyak memberikan pernyataan setuju dan sangat setuju yang dimana pembelajaran tidak terfokus didalam kelas dan tidak membuat siswa jenuh dalam pembelajaran, sedangkan respon siswa terhadap guru daam mengelola pembelajaran hasil dari pernyataan angket yang diberikan banyak siswa yang merespon baik dalam pembelajaran dimana siswa banyak yang menjawab setuju dan sangat setuju dalam setiap pernyataan ya ng di fokuskan ke prose pembelajaran, dan siswa merasa senang dan menemukan pembelajran yang berbeda dari pembelajaran - pembelajaran yang biasa mereka terima. Setelah dianalisis diperoleh data bahwa 25 siswa atau 94,29\% siswa Kelas X 1 memberi tanggapan sangat baik dan 2 siswa atau $5,71 \%$ memberi tanggapan baik. Dapat diartikan bahwa pembelajaran dengan menerapkan konten e-learning berbasis scorm ini efektif utuk digunakan dalam mata pelajaran biologi dengan sub materi tentang tumbuhan berbiji.

Berdasrkan hasil data penelitian yang diperoleh efktifitas pembelajaran sudah tercapai dimana data dari pengujian hipotesis yang menggunakan uji Mann Whiteney menghasilkan $\mathrm{H}_{\mathrm{a}}$ diterima dan $\mathrm{H}_{0}$ ditolak sehinggga mendapat kesimpulan bahwa penerapan konten e-learning berbasis scorm dapat meningkatkan efektifitas pemebelajaran.

Adapun kelebihan dan kekurangan pembelajaran dengan menerapkan konten $e$ learning berbasis scorm yang dialami oleh peneliti selama kegiatan pembelajaran berlangsung adalah sebagai berikut:

1. Kelebihan pembelajaran dengan menerapkan konten e-learning berbasis scorm, diantaranya:

a. Dengan penerapan konten e-learning berbasis scrom inin siswa akan terbiasa mencari dan menjelaskan materi yang didapat.

b. Pembelajaran dapat dilaksanakan dimana saja dan kapan saja sesuai dengan keinginan siswa tersebut.

c. Memberikan suasana belajar baru terhadap siswa agar lebih menyenangkan ketika menerima pemebelajaran.

d. Memaksimalkan pemberian materi yang bersifat dengan contoh agar dapat lebih dipahami oleh siswa.

2. Kekurangan pembelajaran dengan menerapkan konten e-learning berbasis scorm, diantaranya:

a.Kurangnya fasilitas komputer dalam melaksanakan pembelajaran dengan menerapkan konten e-learning berbasis scorm.

b. Siswa masih belum terbisasa dengan pembelajaran seperti ini.

\section{V.SIMPULAN}

Berdasarkan data dan analisis hasil penelitian yang telah dilakukan tentang penerapan konten e-learning berbasis scorm pada pelajaran Biologi dengan materi Tumbuhan Berbiji untuk meningkatkan efektifitas pembelajaran dapat disimpulkan bahwa:

1. Hasil pengemasan dari konten e-learning berbasis scorm, didalam pembelajaran dapat lebih maksimal dalam proses pembelajaran 
memeberikan warna baru dalam pembelajaran dimana materi yang di sampaikan kepada siswa sudah terbuat dalam bentuk powerpoint yang dipadukan dengan aplikasi Ispring yang menunjang dalam format scorm penyampaian materi bisa lebih efektif dalam pembelajaran dan pengawasn guru lebih efktif dalam pengawasan siswa dalam belajar.

2. Penerapan konten e-learning berbasis scorm secara signifikan dapat lebih meningkatkan efektifitas dengan taraf perbandingan kelas eksperimen sebesar 0,51 dilihat dari data gain ternormalisasi sedangkan kelas kontrol sebesar 0,25, pembelajaran pada matapelajaran Biologi dengan materi Tumbuhan berbiji dibandingkan dengan pembelajaran yang menerapkan pembelajaran konvensional.

\section{DAFTAR PUSTAKA}

[1] Asmar. GS.2015. Perbedaan Peningkatan Kemampuan Preoses Pemecahan Masalah tara Siswa Yang Mendapatkan Model Kooperatif Tipe Thinking Aloud Pair Problem Solving (TAPPS) Dan Model Kooperatif Tipe Creatif Problem Solving (CPS).skripsi STKIP Garut.tidak diterbitkan

[2] Bariah, S. H. 2016. Implementasi Konten E-Learning Berbasis Standarisasi Scrom (Shareable Content Object Reference Model) Di Jurusan Pendidikan Teknologi Informasi. Jurnal PETIK Vol.2 No.1, hlm.

[3] Bariah, S.H. 2016. Penerapan ELearning Pada Mata Pelajaran Prakarya Untuk Meningkatkan Keterampilan Berpikir Kreatif Peserta Didik (Studi Kasus Materi Pengolahan Makanan Awetan Nabati) . Jurnal PETIK. Vol.2 No.2, hlm.

[4] Bariah, S.H. \& Kuntum, A. I. 2017. Pengembangan Evaluasi dan Penugasan Online Berbasis E-Learning Dengan Moodle Pada Mata Kuliah Media Pembelajaran Ilmu Komputer. Jurnal Nasional Pendidikan Teknik Informatika. Vol 6, No 3, hlm. 305-315.

[5] Bariah, S.H. \& Kuntum, A. I. 2018. Implementasi Blended Learning Berbasis Moodle Pada Jurusan Pendidikan Teknologi Informasi. Jurnal PETIK Vol4, No.2. hlm.106-113.
[6] Clark, R.C. \& Mayer, R.E. (2008). Elearning and the science of instruction: proven guidelines for consumers and designers of multimedia learning, second edition. San Francisco: John Wiley \& Sons, Inc

[7] Darmawan, D. \& Siti, H. B. 2014. Pengembangan E-Learning Berbasis Mooddle dan Facebook pada mata pelajaran TIK. Jurnal Teknodik 18(3), hlm. 227-240.

[8] Dunne, Richard. 1996. Pembelajaran Efektif (Terjemahan). Jakarta: Grasindo.

[9] Kusmana A. 2011. e-learning dalam pembelajaran. Jurnal Lentera Pendidikan. 14 (1):3551.

[10] Lanzilotti R, C Ardito, MF Costabile, \& AD Angeli. (2006). Else methodology: a systematic approach to the e-learning systems evaluation. Educational Technology \& Society Journal. 9 (4):4253.

[11] Munir,(2008).Kurikulum Berbasis Teknologi dan Komunikasi.Bandung: Alfabeta

[12] Prawiradilaga DS. (2004). Mozaik Teknologi Pendidikan. Jakarta: Kencana Prenada Media Group.

[13] Popham, W. James. 2003. Teknik Mengajar Secara Sistematis (Terjemahan).Jakarta: Rineka cipta

[14] Rahadi, M. (2009). Statistika Parametrik, Modul Kuliah Pada Jurusan Matematika STKIP GARUT.Tidak diterbitkan

[15] Riyanto,S. (2013)Teknologi Informasi Pendidikan Yogyakarta : Gava Media.

[16] Rice, W. H. (2006). MOODLE eLearning Course Development, complete guide to successful learning using Moodle. BirminghamMumbai:PACKT Publishing.

[17] Sinambela, N.J.M.P. (2006). Keefektifan Model Pembelajaran Berdasarkan Masalah (Problem-Based Instruction) Dalam Pembelajaran Matematika untuk Pokok Bahasan Sistem Linear dan Kuadrat di Kelas X SMA Negeri 2 Rantau Selatan Sumatera Utara. Tesis. Surabaya : Program Pasca Sarjana Universitas Negeri Surabaya

[18] Susanty, Wiwin dan Oriiniati, Putri. (2013). 
p-ISSN : 2460-7363

e-ISSN : 2614-6606

[19] Analisis Website E-Learning Berbasis

[20] Standar Scorm Content Aggregation Model 2.1 Di Fakultas Ilmu Komputer Universitas Bandar Lampung. Jurnal Manajemen Sistem Informasi Dan Teknologi. 